\title{
ミツバチの代替ポリネーターとしてのヒロズキンバエの利用
}

\author{
花田惊史 ${ }^{1} \cdot$ 吉田裕一 ${ }^{1} * \cdot$ 佐藤卓也 ${ }^{2} \cdot$ 後藤丹十郎 $^{1} \cdot$ 安場健一郎 ${ }^{1} \cdot$ 田中義行 ${ }^{1}$ \\ 1 岡山大学大学院環境生命科学研究科 700-8530 岡山市北区津島中 \\ 2 (株) ジャパンマゴットカンパニー７00-0867＼cjkstart岡山市北区岡町
}

\section{Utilization of Phaenicia sericata Meig. (Green Blow Fly) as an Alternative Pollinator to Honey Bee}

\author{
Atsushi Hanada ${ }^{1}$, Yuichi Yoshida ${ }^{1 *}$, Takuya Sato ${ }^{2}$, Tanjuro Goto ${ }^{1}$, Ken-ichiro Yasuba $^{1}$ and Yoshiyuki Tanaka ${ }^{1}$ \\ ${ }^{1}$ Graduate School of Environmental and Life Science, Okayama University, Tsushima-naka, Kita-ku, Okayama 700-8530 \\ ${ }^{2}$ Japan Maggot Company, Okamachi, Kita-ku, Okayama 700-0867
}

\begin{abstract}
Colony collapse disorder of the honey bee has been a serious problem throughout the world and farmers often face the insufficient supply of colonies. The shortages of bees have increased the cost to farmers renting them and resulted in a significant decrease in agricultural production. As an alternative pollinator to the honey bee for greenhouse crops, we investigated the practical utility of Phaenicia sericata Meig. (green brow fly), which is propagated artificially for medical maggot therapy. The efficiency of pollination was evaluated by applying a certain number of fly pupae to flowering strawberries, tomatoes, eggplants, and melons. For tomatoes, eggplants and melons, no significant increase of fruit set or in the number of seeds was noted in open pollinated fruit compared to flowers bagged with fine nets to prevent the visiting of flies or other insects. On the contrary, flies frequently visited strawberry flowers just after emergence from pupae and the rate of mis-shapen fruits decreased significantly compared to the fruits developing from flowers before emergence. Pollination efficiency was insufficient in some cultivars, when 400 pupae were applied in a $90-\mathrm{m}^{2}$ plastic house. However, the efficiency was comparable to the honey bee when 1,000 pupae were applied in the plastic house.
\end{abstract}

Key Words : maggot therapy, mis-shapen fruits, spider, strawberry, varietal difference キーワード : 品種間差, イチゴ, 受精不良果, クモ, マゴットセラピー

\section{緒言}

栽培植物の大半を占める被子植物の花は, 虫媒花が多く, 結実のためには昆虫による花粉媒介を必要とする。 セイヨ ウミッバチ (Apis mellifera L., 以降ミッバチとする) は数 少ない家畜化された昆虫の一つであり，長い歴史の中で飼 育技術が蓄積され，世界中で飼養されている（Garibaldi ら， 2013). 我が国でも, 長年にわたって花粉媒介昆虫として イチゴ (Fragaria × ananassa Duch.) をはじめとする多く の作物栽培に利用されている。 しかし，ネオニコチノイド 系の農薬使用が原因として疑われているミッバチの大量死 (van der Sluijs ら, 2013) や, オーストラリアでのノゼマ 病流行による女王蜂の輸入停止（Yan, 2009）など，近年, 供給が不安定化する要因が増加して招り, しばしばミッバ チの不足が問題となっている. さらに, 病害虫防除に使用

2015 年 2 月 20 日 受付. 2015 年 9 月 9 日 受理.

本報告の一部は園芸学会平成 26 年度秋季大会に打いて発表した.

* Corresponding author. E-mail: yyoshida@okayama-u.ac.jp
する薬剤に関する制約, 紫外線要求性（みつばち協議会, 2011），低温や高温などによる活動不良（宮本，2012）の ほか，過剩訪花による障害発生（西本ら，2012）などミッ バチを利用するに当たっては様々な課題がある.

多様なミッバチの代替手段が確立されれば，これらの問 題を回避できると考えられ，作物生産の安定化に大きく寄 与すると期待される. 海外では，ヨーロッパ原産のセイヨ ウオオマルハナバチ（Bombus terrestris L.）が花粉媒介昆 虫として実用化されて扣り (Goulson, 2010)，我が国でも 一時期施設栽培トマトを中心に広く利用された。しかし， 生態系への悪影響が懸念されるため, 現在は特定外来生物 に指定され，利用が制限されている（米田ら，2008）。 こ れを受けて，在来種であるクロマルハナバチ (Bombus ignites Smith）への切り替光利用が進められた（光畑, 2014） が，国内でも北海道など一部生息が確認されていない地域 があり，この種に扣いても生態系への影響が懸念されてい

る(米田ら, 2008).

これらの八チ類と同様，八工類は自然界で多くの植物種 の花粉媒介昆虫として働いていることが知られている（田 
中, 1994). 以前は, シマハナアブ (Eristalis cerealis Fabricius）が花粉媒介昆虫として生産・販売されていた（小 林, 1972）が, 飼料の悪臭問題と採算上の理由から生産が 中止された(JATAFF, 2015). 現在では, マンゴー(Mangifera indica L.）の施設栽培に沶いて，八工類が花粉媒介昆虫々 して利用されている(水野ら，2010）。その中の一つであ るヒロズキンバエ (Phaenicia sericata Meig.) は, 糖尿病 性壊疽患者に対するマゴット七ラピーに用いられて拉り （三井ら，2005)，（株）ジャパンマゴットカンパニーは, このヒロズキンバエの人工飼育技術を確立して，医療用に 供給している，女王蜂の供給を輸入に頼る部分の大きいミ ッバチに対して, ヒロズキンバエは国内で生産できるため, より安定的な供給が可能と考えられる。また，ヒロズキン バエは日本全土に分布する在来生物であるため, 生態系へ の影響を考慮する必要がない，さらに，八チ類と比較して 幅広い温度条件下で活発に活動するため, 施設栽培の多様 で過酷な環境条件に対応する能力を持つと考兄られている (ジャパンマゴットカンパニー，2015)。実際に，イチゴの 施設栽培に执いて，野焼きの煙でミッバチが活動を停止す る様な条件下でもヒロズキンバエは活発に活動し, 盛んに 訪花することが確認されている (吉田, 未発表)。これら のような特徵から，七ロズキンバエは八チ類に代わる花粉 媒介昆虫として, 様々な施設栽培作物に利用できる可能性 が高い。

八工類は, 動物の糞や腐熟した肉などを餌として幼虫が 成長する種が多い（福田，1960）ため，衛生害虫に分類さ れることが多い（末永，1959）。しかし，七ロズキンバエ は八チ類のように人に危害を加光る毒針を持たず，衛生的 に人工飼育されたサナギは手軽に利用可能であるため, 農 業生産の広範囲な場面で利用できる可能性がある. サナギ を搬入するだけで利用可能であるため，作物の開花期に合 わせて，導入時期や導入数を調整することが容易ならえ， ミッバチのように, 巣内での繁殖を考慮する必要がないた め, 病害虫防除に使用する農薬に関する制約が少ないと考 えられる。

本研究は, ミッバチに代わり得る新たな農業用の花粉媒 介者として，ヒロズキンバエの実用性を調査することを目 的とした，著者の一人である佐藤が，農水省の補助金を受 けて行った市場調査によって, マンゴーやメロン（Cucumis melo L.）なぞ開花期の短い作物では農薬使用上の制約が少 ない点が, ナス (Solanum melongena L.) やトマト (Solanum lycopersicum L.) では活動可能温度域が広い点が，新たな 花粉媒介昆虫として特に大きく期待されるとの結果が得ら れている (未発表)。本研究では，イチゴに対する受粉効 果を検証するとともに，昆虫の訪花による振動が主たる受 粉効果を持つナス科野菜と, イチゴと同様に昆虫の送粉が 主たる効果を持つメロンについての実用可能性を明らかに することを目的とした．

\section{材料および方法}

\section{1. イチゴ}

2011 年, 2012 年, 2013 年の各年 9 月中旬に, 岡山大学 実験圃場の面積 $90 \mathrm{~m}^{2}(6 \mathrm{~m} \times 15 \mathrm{~m})$ の無加温八ウスに定 植したイチゴの株を用いて，ヒロズキンバエ（以降八エと する）による受粉効果を調查した．各年畧幅 $110 \mathrm{~cm} の$ 畧 を 5 畧立て，シルバーマルチで覆った．植物は株間 $20 \mathrm{~cm}$ で 1 畧につき約 120 株を 2 条植えした。元肥は施用せず 複合液肥 OK-F-1（N- $\mathrm{P}_{2} \mathrm{O}_{5}-\mathrm{K}_{2} \mathrm{O}=16-10-14, \mathrm{OAT}$ アグリオ (株)） $180 \mathrm{~g}$ を週に 1 回, 液肥混入器とマルチ下に敷設し た灌水チューブを用いて施用した．八エは直径 $8 \mathrm{~cm}$ の円 形の透明プラスチックケースに，サナギの状態で入ったも のを搬入した．当初はプラスチックケースを直接畧の上に 置いたが，八ウス内で徘徊性のクモ類が大量に増殖し，サ ナギを食害し羽化を阻害することが確認された後は，天井 からひもで地面から約 $1.5 \mathrm{~m}$ の高さに吊り下げた. 搬入後, 毎日プラスチックケース内を観察し，ケース内に 1 頭以上 の成虫が観察できた日を八エの羽化開始日とした。いずれ の品種も 8 花 / 果房となるよう摘花した。振動による受粉 を避けるため，開花日の記録掞よび花のラベルは，開花当 日の午前 10 時まで(開葯前) 飞行った、いずれの調査日も， 5〜20 花をラベルした．果実が成熟した段階で収穫して, 瘦果と果床の発育程度によって正常果と受精不良果に分類 した，一部に不受精の瘦果があっても，ほぼ均一に肥大し た果実は正常果に分類した.

\section{1）ミツバチとの受粉効果の比較}

2010 年秋に購入し，夏越ししたミッバチの巣箱（7 枚型 木箱入り 4 枚群 +1 , （有）間室養蜂場）をイチゴの開花 に合わせ，2011 年 11 月中旬に搬入した。 この巣箱を，12 月 19 日まで八ウス北西端に置いた高さ $23 \mathrm{~cm}$ のコンテナ 上で管理した。 12 月 20 日早朝に八ウス内にミッバチが飛 行していないことを確認してから，巣箱をハウスから搬出 した。 ミッバチ搬出翌日の 12 月 21 日に八エのサナギ 3000 頭を，3つのプラスチックケースに分けて搬入し， 八 ウス内の異なる畧の上に置いた。 八エの飛行が確認できな くなった 2012 年 1 月 20 日に再びミッバチの巣箱を搬入し た。 ‘紅ほっぺ’を供試し，ミッバチ搬出前（2011年 12 月 $15 \sim 19$ 日)，サナギの $80 \%$ 程度が空になった後（2011 年 12 月 27 日〜 2012 年 1 月 4 日), 八工の飛行頭数減少後 (2012 年 1 月 $12 \sim 15$ 日)， ミッバチ再搬入後（2012 年 1 月 $22 \sim 26$ 日）に分けて，それぞれの期間中に咲いた花を ラベルし，成熟した果実を評価した。

\section{2）受粉効果の品種比較}

品種による受粉効果の差についても調査するため, ‘さ がほのか’, “紅ほっぺ”, “福岡 S6 号’の3 品種を用いて 調查した。 2012 年 11 月 12 日までミッバチを放飼し，11 月 10 日拉よび 11 月 15 日に八エのサナギをそれぞれ 1000 頭ずつ八ウスに搬入した。.八ウス内で八エの飛行が確認で 
きなくなった 12 月 10 日に再びミッバチを搬入した。 各品 種 11 月 9 日，14 日，20日，30日，12月 3 日，7 日，12 日 に開花した花をラベルし, 成熟した果実の正常果率を調査 した.

\section{3）複数回放飼による受粉効果の変化}

“さがほのか’は2013 年 10 月 26 日から 11 月 11 日まで, “さちのか’と“福岡 S6 号” は11月 7 日から 11 月 20 日 まで，それ攵れ毎日開花当日の花をラベルし，成熟した果 実の形態を評価した。.八エのサナギは 10 月 28 日， 11 月 3 日，11月9日，11月 16 日にそれぞれ 400 頭ずつ搬入し， 11 月 8 日には, アブラムシ類防除を目的として, ミッバ チに対して長期間悪影響を及洔す殺虫剂ペルメトリン（ア ディオン乳剂 3000 倍液, 住友化学（株））１０Ｌを散布した。 その結果八エはほぼ全頭死滅し，翌日から飛行はまったく 観察されなくなった.

上記の 3 品種について，2014 年 2 月 7 日から 5 月 7 日 まで $2 \sim 4$ 日ごとに開花当日の花をラベルし, 成熟した果 実の形態を評価した。八エのサナギを 2 月 12 日，26日， 3 月 3 日，24日，28日，4月 3 日， 7 日に 400 頭ずつ搬入 した。このらち 3 月 3 日拉よび 3 月 24 日に搬入したもの は注とんぞ羽化せず，3月 28 日に搬入したものはまった く羽化しなかった. 徘徊性のクモ類の食害を避けるために, 4 月 3 日以降はサナギ入りのプラスチックケースを八ウス 内に吊り下げたところ, その後は盛んに羽化することが確 認された， 4 月 15 日にアザミウマ類防除のため, 殺虫剤 スピノサド（スピノエース水和剤 5000 倍液, ダウ・ケミ カル日本（株）） $10 \mathrm{~L}$ を散布したところ，翌日ハウス内で 八エが飛行する姿は観察されなくなった，その後，放飼頭 数に上る打打上その受粉効果の差異を推定するため, 4 月 24 日から 5 月 3 日まで 3 日間ごとに 4 回，100 頭ずつ搬入 した.

\section{4）花粉の稔性調査}

2014 年 2 月 28 日拈よ゙ 4 月 10 日飞“さがほのか’，“さ ちのか’, ‘福岡 S6 号’ の開花前日の花を, 内側が雌ずい に触れないように薬包紙で作成した袋で被覆し, 被覆 1 週 間後に薬包紙ごと花を手で振動させることで花粉を採取し た. 花粉は両日ともに，各品種異なる株由来の $4 \sim 5$ 花か ら採取した。乾燥花粉を酢酸カーミンで染色し, 光学顕微 鏡を用いて 100 または 200 倍で観察した。染色されなかっ た花粉, 小さい, あるいは形が不整形な花粉を異常花粉と して，正常花粉率を記録した。

\section{2. トマト，ナスおよびメロンへのヒロズキンバエの受粉 効果}

2013 年は, イチゴと同じ無加温八ウスでナスおよびメ ロンを, 岡山大学農学部附属山陽圏フィールド科学セン タ一内のガラス温室でトマトをそれぞれ栽培し, これらの 果菜類に対する八エの受粉効果を調查した。 無加温八ウス については畧幅 $180 \mathrm{~cm}$ の畧を 3 畧立て, そのすべてをシ ルバーマルチで覆った. 八ウス東西両端の 2 畧にメロンを,
中央の畧にナスを定植した。

1) メロン

‘パパイヤ’拉よび‘ラブコール’ (いずれも愛三種苗(株)) の 2 品種を供試した。 2013 年の 3 月 5 日に播種し，4 月 13 日に定植した。株間 $40 \mathrm{~cm}, 1$ 条植えで各品種 32 個体 ずつ定植し，主枝を第 4 節で摘心，子づる 2 本仕立ての立 体栽培を行った．各子ら゙るの第 $11 〜 13$ 節の孫づるのみを 残し，他の孫づるはすべて取り除いた，残した孫づるの第 1 節に着生した雌花を調査対象とし，第 2 節で摘心した. すべての子づるを第 $22 ２ 4$ 節で摘心した．それぞれの雌 花には，人工交配区，八工受粉区（以下放任区とする）, 袋かけ区を設け，“パ゚イヤ’についてはさらに4-CPA（ト マトトーン，石原産業（株））処理区を設けた。 人工交配 は別個体由来の雄花を摘久取り, その葯を雌花の柱頭にこ すりつけることで行った. 4-CPA 処理は 4-CPA 300 ppm 液 を, 開花前の雌花の花梗部に噴霧した. 人工交配预よび 4-CPA 処理は, 開花当日の午前 10 時までに行った。袋か け区は八エの訪花を防ぐために，開花 $1 \sim 2$ 日前の雌花を 約 $2 \mathrm{~mm}$ 目合いのネット（ストッキングタイプ水切り袋, 日本技研工業（株），以降ネットとする）で覆った，放任 区は無処理とした. 処理による着果負担の偏りを防ぐため, 同一の子ら゙るに着生する雌花には，互いに異なる処理を 行った。調査対象は 5 月 16 日から 5 月 23 日までの間に開 花した雌花とし, それ以降に開花したものはデータに含め なかった。

\section{2) ナス}

‘とげなし千両”拈よび‘SL紫水’（いずれもタキイ種 苗(株)）の 2 品種を供試した。 2013 年 1 月 9 日に播種, 3 月 4 日にナス “耐病 VF' (タキイ種苗（株））を台木と して接ぎ木し，4月 12 日に 20 個体ずつ株間 $60 \mathrm{~cm}$, 条間 $40 \mathrm{~cm}$ で 2 条植えした. 主枝一本仕立てとして切り戻し整 枝を行い，6月 4 日から 6 月9 日までに開花した花を調査 対象とし，振動受粉区，放任区，袋かけ区の 3 処理区を設 けた，株の振動による受粉を避けるため，調査対象の花は すべて開花前にラベルを行った．振動受粉区は開花当日の 花のがく部分を，2，3 度指で軽くはじいた。袋かけ区は 開花前の蕾で，花弁が見えるよらになったものをネットで 覆った．放任区は無処理とした．各処理区 $3 \sim 5$ 花の反復 を設け, 果実は開花後 30 日以上が経過し, 果皮のつやが なくなり始めた時点で収穫した. 着果率と成熟果の種子数 を記録した。

これらのメロン打よびナスの開花に合わせ，八エを 5 月 10 日，17日，6月 2 日，6日，10日に，サナギの状態で 1000 頭ずつハウスに搬入した。 サナギ入りのプラスチッ クケースは，いずれもナス ‘とげなし千両”と 'SL 紫水” の境界に当たる植物群落内の畧上に設置した.

3) トマト

“シンディースイート’（(株）サカタのタネ）を，2013 年春季（播種: 2012 年 12 月 28 日, 定植: 2013 年 2 月 6 日) 
と, 秋季（播種: 2013 年 7 月 18 日, 定植: 2013 年 8 月 8 日） に, 吉田ら（2010）と同様の方法で $12 \mathrm{~cm}$ 黒ポリポット（培 地容量 $600 \mathrm{~mL}$ ）に植え付けて栽培した。秋季には“桃太 郎ファイト’（タキイ種苗（株））を供試品種に加え，“シ ンディースイート’ と同様の方法で栽培した. 処理区とし て 4-CPA 処理区，振動受粉区，放任区，袋かけ区の 4 処 理区を設け，各処理区 3 個体ずつ供試した。“シンディー スイート’ は， 1 果房当たり 8 花，“桃太郎ファイト’ は 1 果房当たり 3 花になるよら，それぞれ摘花した。 4-CPA 処 理区は開花中の果房に 1 度だけ4-CPA 15 ppm 液を噴霧し た. 振動受粉区は開花している果房がある限り，2３日 ごとに株全体を振動させた。放任区は着果促進に関する処 理は行わなかった. 袋かけ区は開花前の果房を摘蕾して花 数を調整した後, ネットで全体を被覆した，春季は，“シ ンディースイート’ の第 $1 \sim 9$ 果房を, 秋季は ‘シンディー スイート’ の第 $1 〜 5$ 果房，执よび ‘桃太郎ファイト’の 第 1 〜 果房をそれぞれ調査対象とし, 果房ごとの着果率 を記録した。着果率は, 収穫果数を摘花処理時に残した花 数（“シンディースイート’: 8 花，“桃太郎ファイト’:3 花） で除することで算出した。，八エを，春季は 3 月 29 日から 5 月 17 日までの間， 2 週間ごとに，秋季は 9 月 3 日から 9 月 25 日までの間，4〜5日ごとに，それぞれ 3000 頭ずつ サナギの状態で八ウスに搬入した. いずれも一度の搬入に つき，1000頭ずつ入ったプラスチックケースを $3 つ ，$ 互 いに $2 \mathrm{~m}$ 以上離して, 調査個体群落内の床面に設置した.

1. イチゴ

\section{1）ミツバチとの受粉効果の比較}

12 月 15 日から 12 月 19 日までのミッバチ放飼期間中に 開花した 紅ほっぺ’では約 $80 \%$ が正常果であった（第 1 図)。12月 20 日にミッバチを搬出し，その翌日 12 月 21 日にハエ 3000 頭を搬入したところ，搬入 2 日後から羽化 が始まった。，八エの羽化開始日については，いずれの実験 に扮いても医搬入当日または翌日と大きなばらつきは認 められなかった。 このため, 以降, 搬入当日から翌日まで に羽化開始したものについては羽化開始日に関する記述を 省略した. 八工搬入後 7 日目から 14 日目までに開花した 花は正常果率が約 $70 \%$ であり， $\chi^{2}$ 検定の結果 $P \fallingdotseq 0.363$ となり, ミッバチと棌同等の効果があると判断された. しかし，搬入後 3 週間が経過した 1 月 12 日から 1 月 15 日 までに開花した花は, 正常果率が $40 \%$ 未満となり，正常 果率は有意に低下した。 八エの飛行が確認されなくなった 1 月 20 日に再びミッバチを搬入したところ，1月 22 日か ら 1 月 26 日までに開花した花は $80 \%$ 以上が正常果となった.

\section{2）受粉効果の品種比較}

ミッバチ放飼期間中は全品種で受精不良果が現れなかっ た（第 2 図）。八さを11月 10 日と 11 月 15 日にそれぞれ 1000 頭ずつ搬入したところ，ミッバチと同等の効果が約 2

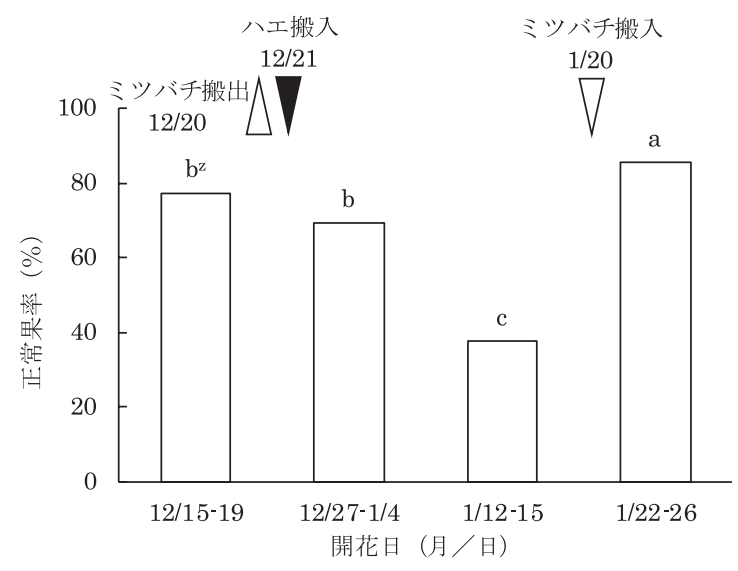

第 1 図 ミッバチと八エによる受粉が “紅ほっぺ”の正常果 率に及ぼす影響（2011-2012）

白の三角はミッバチの搬出日（12/20）扎よび搬入日 （1/20）を示し，黒の三角は八エのさなぎ 3000 頭を搬 入した日 $(12 / 21)$ を示す

z 異なる文字間に, $P<0.05$ で有意差があることを示す （カイ二乗検定による逐次比較）

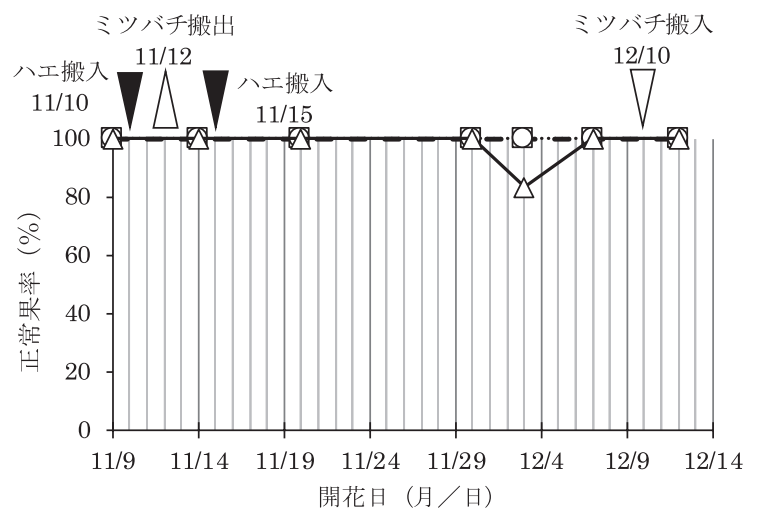

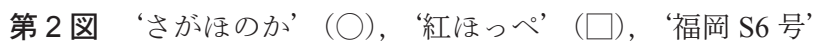
(メ) の正常果率の推移 (2012)

黒の三角は八エのさなぎ 1000 頭を搬入した日（11/10 および11/15）を示し，白の三角はミッバチの搬出日 （11/12）打よび搬入日（12/10）を示す

週間継続し，11月 30 日までに開花した花はいずれの品種 についても受精不良果が発生しなかった。 しかし，搬入後 約 3 週間が経過した 12 月 3 日には“福岡 S6 号’ で正常 果率の低下が見られ，約 $17 \%$ が受精不良果となった。一 方で，“紅ほっぺ’と‘さがほのか’では搬入後 3 週間以 上経過しても受精不良果が発生しなかった。 また，ミッバ チを 12 月 10 日に再度搬入したところ，“福岡 S6 号’に拉 いて搬入 3 日前に開花した花でもすべて正常果となった.

\section{3）複数回放飼による受粉効果の変化}

10 月下旬から開花が始まった“さが皃のか’では八エ の受粉効果が高く，安定していた（第 3 図）．八工搬入前 およびペルメトリン散布後に開花した花では正常果率が $30 \%$ 未満であったが，搬入 2 日後に羽化が始まってからぺ ルメトリン散布までの間に開花した花は注ぼすべてが正常 果であった。 また羽化開始 1 日前に開花した花から正常果 


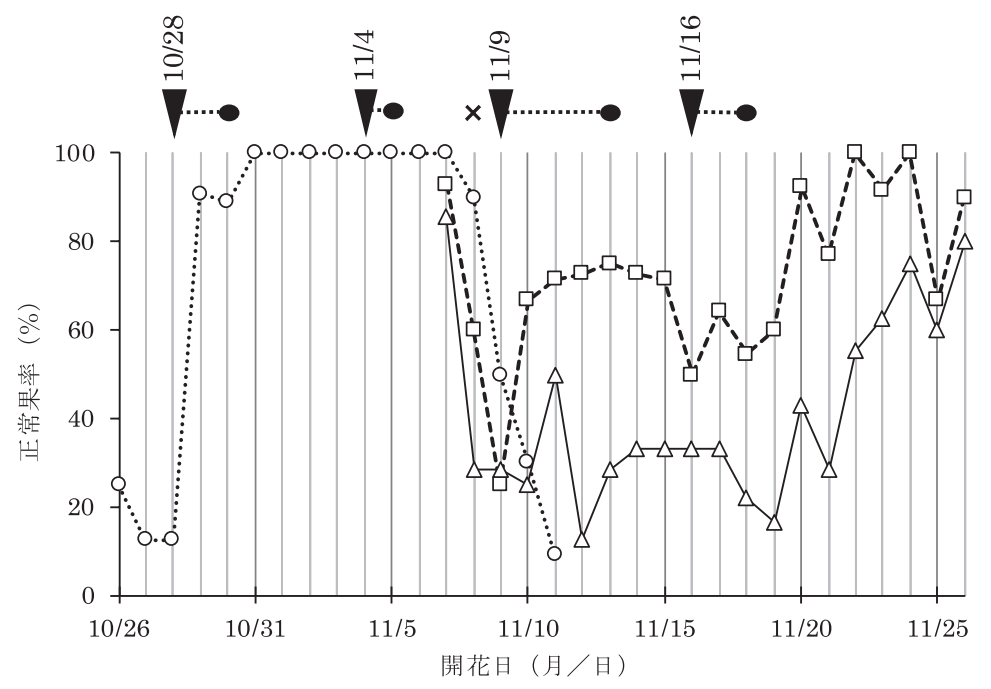

第 3 図 ‘さがほのか’ (○)，“さちのか’ $(\square)$ ，“福岡 S6 号’ $(\triangle)$ の正常果率の推移 (2013)

黒の三角は八エ 400 頭を搬入した日を示し，三角形と点線で結ばれた黒丸はとの八エが羽化を開始した日を示す。×は殺 虫剂（ペルメトリン）を散布した日を示す

率は 80\%を越えていた。

‘さちのか’ではペルメトリン散布前日に開花した花の 正常果率は $90 \%$ 以上であったが，八エの飛行が確認され なくなった散布翌日に開花した花は正常果率が $30 \%$ 以下 に低下した。 11 月 9 日に搬入した八エ（以後ハエ 11/9-400 とする）は羽化が搬入 4 日後からとなり，それまでより遅 かった．八エ 11/9-400の羽化が始まる3 日前に開花した 花から正常果率は 60\%を越えたが，11月 16 日に搬入した 八エ（以後八エ 11/16-400 とする）の羽化が始まるまでに 開花した花は，正常果率は高くとも70\%程度にとどまっ た. 八エ 11/16-400の羽化が始まった 11 月 18 日以降は徐々 に受粉効果が高まり，正常果率は $80 \%$ を越光た。

“福岡 S6 号” に打いてもペルメトリン散布後急激に正 常果率が低下した。 八エ11/9-400が羽化しても直ちに正 常果率は上昇せず，注湆30\%前後で推移した。 八エ 11/16400 の羽化開始以降に開花した花の正常果率は, 徐々に高 くなり，11月 26 日に開花した花は $80 \%$ が正常果となった.

2 月から 5 月に開花した花の正常果率の変化を第 4 図に 示した。 2 月 12 日に搬入した八エ（以降八エ 2/12-400 と する）は羽化が遅く，2月19 日に羽化を開始した。 この 八エを搬入した 2 月 18 日までに開花した花はいずれの品 種も正常果率は 40\%以下であった。 ‘さが泳のか’と‘さ ちのか’は，八エの羽化開始当日から受粉効果が現れ，“さ が核のか’に沶いては 2 月 22 日に開花した花の $90 \%$ が正 常果となった。一方で, “福岡 S6 号” は羽化が始まって も直ちに受粉効果は現れず，羽化が始まってから 3 日後の 2 月 22 日に開花した花から正常果率が徐々に高くなり始 めた. 八エ 2/12-400 による受粉効果は 3 月 1 日以降急激 に低下し，3 月 4 日に開花した花は全品種で正常果率が $30 \%$ 未満となった。 3 月 3 日，24日，28日に搬入した八 エは，ほとんど羽化せず，3月 3 日から 28 日の間は八エ
の訪花が注とんど確認できなかった。 この期間に開花した 花の正常果率はいずれの品種も0～40\% と非常に低く推 移した。

12 月以降，八ウス内ではコモリグモ科（Lycosidae）を 中心に徘徊性のクモ類が大量に発生していた．羽化しな かったサナギは内部が空洞になって抒り，これらのクモ類 が八エのサナギを捕食していた可能性が考兄られた，実体 顕微鏡下で観察したところ, クモ類の食害痕と思われる傷 が確認された。 このため以降の八エは，八ウス天井からひ もでサナギ入りのプラスチックケースを吊り下げてクモ類 から隔離した。すると 4 月 3 日に搬入した八エ（以降八工 4/3-400 とする）は，搬入当日から羽化を始め，翌日には 八ウス内で八エが盛んに飛行して訪花する姿が観察され た。 その結果，4月 2 日に開花した花の正常果率は 3 品種 とも $60 \%$ 以上となり，“さが汪のか’では 4 月 5 日に開花 した花のすべてが正常果となった。，八エ 4/3-400 がまだ死 滅していない 4 月 7 日に，さらに 400 頭の八エを搬入した ところ, 翌日 4 月 8 日から羽化を始め, その後も順調に羽 化した。“さちのか’と“福岡 S6 号”に拈いては4月 7 日 までに開花した花の正常果率は $70 \%$ 前後にとどまってい たが，4月10日に開花した花はこれらの品種でもすべて が正常果となった。 その後，4月14日に開花した花でも 全品種で正常果率は $100 \%$ となった４月 15 日のスピノサ ド散布により八エの飛行数が急激に減少し，4月 23 日に 開花した花は 3 品種ともすべてが受精不良果であった.

その後，4月 24 日から 3 日ごとに 100 頭ずつの八エを 搬入したところ，4月 27 日に開花した花は全品種で正常 果率が $60 \%$ 以上となった。“さが注のか’と“福岡 S6 号” では 5 月 4 日まで受粉効果の上昇が見られ，5月 7 日には 効果の低下が認められた。一方，“さちのか’は4月 27 日 に開花した花で正常果率が $80 \%$ となり，その後受粉効果 


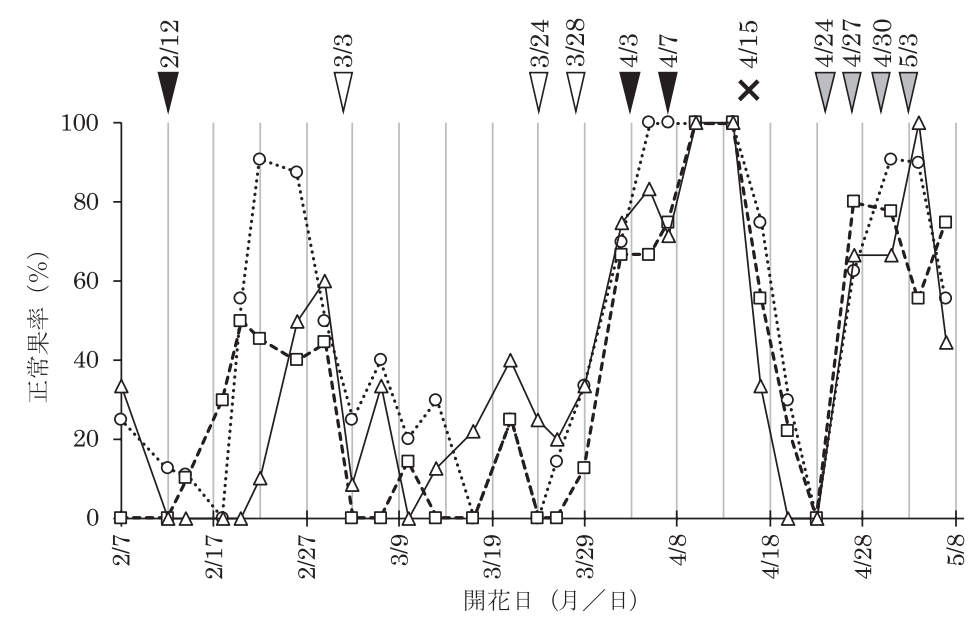

第 4 図 ‘さがほのか’ (○)，“さちのか’ $(\square)$, 福岡 S6 号’ $(\triangle)$ の正常果率の推移 (2014)

グラフ上部の三角は八エを搬入した日を示し，黒い三角は 400 頭を搬入して順調に羽化したもの，白い三角は 400 頭を搬 入して羽化率が悪かったもの, 灰色の三角は 100 頭を搬入して順調に羽化したものを示す. また ×は殺虫剤 (スピノサド) を散布した日を示す

第 1 表 イチゴ花粉の稔性の品種間差異 (2014)

\begin{tabular}{cccc}
\hline \hline \multirow{2}{*}{ 品種 } & \multicolumn{3}{c}{ 正常花粉率 $(\%)$} \\
\cline { 2 - 4 } & 2月 28 日 & 4月 10 日 & 平均 \\
\hline さがほのか & 52.5 & 50.0 & $51.7 \mathrm{a}^{\mathrm{y}}$ \\
さちのか & 88.5 & 87.4 & $88.0 \mathrm{~b}$ \\
福岡 S6 号 & 73.1 & 78.7 & $75.9 \mathrm{~b}$ \\
平均 & 72.7 & 76.7 & \\
\hline
\end{tabular}

酢酸カーミンで採集した花粉を染色し, 光学顕微鏡を用い, 倍率 100 または 200 倍で観察した。形が不整形，あるいは 小さな花粉を異常花粉とし, 正常花粉率を算出した. 各処 理区で 4-5 のサンプルを用い，3度カウントした平均值

${ }^{\mathrm{z}} F$-test により $P<0.05$ で調査日間に有意差なし（アークサ イン変換後二元配置分散分析）

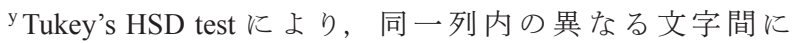
$P<0.05$ で有意差あり（アークサイン変換後二元配置分散 分析)

がわずかに低下し始めた。

\section{4）花粉の稔性調查}

正常花粉率は, ‘さちのか’ と “福岡 S6 号” 上と高かった（第 1 表）。一方，“さが臣のか’ は 50\%程 度と他の品種に比べ有意に低かった. 採取日による正常花 粉率の差は小さかった.

\section{2. トマト，ナスおよびメロンへのヒロズキンバエの受粉 効果 \\ 1)メロン}

5 月 10,17 日に搬入した八エはいずれも順調に羽化し, 調査対象とした雌花の開花期（5月 16～23 日）には，八 ウス内で飛行中の八エが多数観察された. 羽化直後は雄花 が盛んに咲いているにも関わらず，積極的に花に飛来する 様子は観察できなかった. しかし羽化後数日経つと, 雄花 の花弁の表面を歩き回る姿がしばしば観察された。雌花へ の訪花も雄花と同程度に観察されたが，柱頭部に頭をらず めて花蜜を吸らような姿を観察することはできなかった。
第 2 表 八エを放飼したハウス内での雌花への処理がメロン ‘パパイヤ’と‘ラブコール’の着果率に及ぼす影響

\begin{tabular}{|c|c|c|c|c|}
\hline \multirow[b]{2}{*}{ 処理区 } & \multicolumn{2}{|c|}{ ‘パパイヤ’ } & \multicolumn{2}{|c|}{ ‘ラブコール' } \\
\hline & $\begin{array}{c}\text { 処理果数 } \\
\text { (個) }\end{array}$ & $\begin{array}{c}\text { 着果率 } \\
(\%)\end{array}$ & $\begin{array}{c}\text { 処理果数 } \\
\text { (個) }\end{array}$ & $\begin{array}{c}\text { 着果率 } \\
(\%)\end{array}$ \\
\hline 袋かけ & 47 & $0.0 c^{x}$ & 56 & $0.0 \mathrm{~b}$ \\
\hline 八工（放任） & 46 & $0.0 \mathrm{c}$ & 56 & $1.8 \mathrm{~b}$ \\
\hline 人工交配 z & 46 & $39.1 \mathrm{~b}$ & 56 & $58.9 \mathrm{a}$ \\
\hline 4-CPA & 47 & $100.0 \mathrm{a}$ & & - \\
\hline
\end{tabular}

${ }^{\mathrm{z}} 4-\mathrm{CPA} 300 \mathrm{ppm}$ 液を開花前の雌花の花梗部に噴霧した

$\mathrm{y}$ 別個体由来の雄花を摘久取り，その葯を雌花の柱頭にこす りつけた

$\mathrm{x}$ 同一列内の異なる文字間に $P<0.05$ で有意な差があること を示す（カイ二乗検定による総当たり比較）

‘パパイヤ’に拈いて 4-CPA 処理区はすべて着果した（第 2 表)。一方，袋かけ区は両品種ともにまったく着果しな かった．人工交配区は ‘パパイヤ’で $39.1 \%$, ‘ラブュール’ で 58.9\% と，両品種で 6 割にも満たなかった。放任区で着 果したのは，両品種合わせて ‘ラブコール’ に拈りる 1 果 のみであった.

\section{2) ナス}

実験を通してハエがナスの花に飛来する姿は観察できな かった，着果率は両品種ともに，最も小さかった袋かけ区 でも $50 \%$ 以上となった（第 3 表）。着果率が $100 \%$ となっ たのは 'SL 紫水” の振動受粉区のみであった。いずれの 品種に拈いても，平均種子数は放任区と袋かけ区の間に有 意な差は認められなかった。一方振動受粉区は他処理区よ り有意に平均種子数が多く, 放任区の 5 倍以上となった.

\section{3）トマト}

春季も秋季も，ともにハウス内でハエをまったく観察で きない日はなかった，羽化後は，トマト群落内を盛んに飛 び回る姿も観察されたが，訪花する個体を確認することは 
第 3 表 八エを放飼した八ウス内での花への処理がナス ‘とげなし千両”と ‘ SL 紫水”の着果率特よび種子数に及ぼす影響

\begin{tabular}{|c|c|c|c|c|c|c|}
\hline \multirow{2}{*}{ 処理区 } & \multicolumn{3}{|c|}{ ‘とげなし千両’ } & \multicolumn{3}{|c|}{ 'SL 紫水' } \\
\hline & 処理花数（個） & 着果率 y (\%) & 種子数（個） & 処理花数（個） & 着果率（\%） & 種子数 (個) \\
\hline 袋かけ & 4 & 50.0 & $197 b^{x}$ & 4 & 50.0 & $202 \mathrm{~b}$ \\
\hline 八工（放任） & 4 & 75.0 & $201 \mathrm{~b}$ & 5 & 60.0 & $146 \mathrm{~b}$ \\
\hline 振動受粉 z & 3 & 66.7 & $1384 \mathrm{a}$ & 3 & 100.0 & $771 \mathrm{a}$ \\
\hline
\end{tabular}

z 開花当日の花のがく部分を 2,3 度指で軽くはじいた

$\mathrm{y}$ 着果率は $P<0.05$ で処理区間に有意差なし（カイ二乗検定による総当たり比較）

${ }^{x}$ Tukey’s HSD test により，同一列内の異なる文字間に $P<0.05$ で有意差あり

第 4 表 八エを放飼したガラス温室内で，果房への処理が トマト ‘シンディースイート’ と“桃太郎ファイト’ の着果に及ぼす影響

\begin{tabular}{|c|c|c|c|}
\hline \multirow[b]{2}{*}{ 処理区 } & \multirow{2}{*}{$\begin{array}{c}\text { 春季 } \\
\text { ‘シンディー } \\
\text { スイート’ }\end{array}$} & \multicolumn{2}{|c|}{ 秋季 } \\
\hline & & $\begin{array}{l}\text { ‘シンディー } \\
\text { スイート’ }\end{array}$ & $\begin{array}{l}\text { “桃太郎 } \\
\text { ファイト’ }\end{array}$ \\
\hline 袋か忴 & $72.4 b^{x}$ & $21.3 \mathrm{~d}$ & $35.6 \mathrm{~b}$ \\
\hline 八工（放任） & $82.2 \mathrm{ab}$ & $53.0 \mathrm{c}$ & $29.8 \mathrm{~b}$ \\
\hline 振動受粉 ${ }^{\mathrm{z}}$ & 89.9 a & $67.4 \mathrm{~b}$ & $52.0 \mathrm{ab}$ \\
\hline 4-CPA & $87.2 \mathrm{a}$ & $87.7 \mathrm{a}$ & $70.1 \mathrm{a}$ \\
\hline
\end{tabular}

数值は果房ごとの着果率 $(\%)$ を算出し，それらを平均した 值

z開花している果房がある限り 2 ～ 3 日ごとに株全体を振動 させた

y 第 3 花開花中の果房に 1 度だけ 4-CPA 15 ppm 液を噴霧した xアークサイン変換後, Tukey's HSD test そより, 同一列内 の異なる文字間に $P<0.05$ で有意差あり

できなかった，第 4 表に示したとおり, 春季の ‘シンディー スイート’の着果率は，袋かけ区を除く 3 処理区で $80 \%$ 以上になった。 4-CPA 処理区，振動受粉区，放任区の間に 有意差は認められなかったが，袋かけ区は，4-CPA 処理区 および振動受粉区と比較して有意に着果率が低かった。一 方, 秋季の ‘シンディースイート’ の着果率は 4-CPA 処 理区 $>$ 振動受粉区 $>$ 放任区 $>$ 袋かけ区となり，すべての処 理区間で有意な差が認められた。 80\%を越えたのは4-CPA 処理区のみで，袋かけ区はその1/4にも満たなかった。秋 季の “桃太郎ファイト’ は，放任区と袋かけ区で注同等 の着果率となり，これらはともに4-CPA 処理区ょりも有 意に低かった。

\section{考察}

本研究では主要な果菜類で, 施設栽培に打いて八チ類が 受粉に利用されているナス, トマト, メロン持よびイチゴ について調査したが，イチゴ以外は，ヒロズキンバエによ る明確な受粉効果は得られなかった。

メロンについては人工交配区の着果率が高かった ‘ラブ コール’ に拈いても 60\%未満と, “パパイヤ’の4-CPA 処 理区と比較すると高い数值ではなかったが，放任区と袋か け区の着果率が帛 0 であったことから，八エによる受粉 効果は汇とんどないと考えられた（第 2 表）。
ナスでは，着果率に関して，“とげなし千両”，“SL 紫水” の両品種に共通した一定の傾向は見られなかった（第 3 表).一方，種子数についてはいずれの品種に打いても放 任区は振動受粉区と比較して有意に小さく，袋かけ区との 間に有意な差が認められなかった，以上のことから，ナス に拈いては，八エによる実用的な着果促進効果を得ること は困難だと考えられる。

トマトについて，春季の ‘シンディースイート’では， 放任区の着果率が 4-CPA 処理区や振動受粉区と同等となっ たため, 八エによる受粉効果を得られる可能性が期待され た.しかし，秋季は ‘シンディースイート’, ‘桃太郎ファ イト’ いずれに招いても, 放任区の着果率は4-CPA 処理 区ょり 30\%以上小さくなり，その差は有意であった。さ らに，放任区の着果率が，振動受粉区より大きくなること もなかったことに加光，秋季の ‘シンディースイート’を 除いて，放任区と袋かけ区の間に，着果率の有意な差は認 められなかった（第 4 表）、トマトについても受粉効果が ある可能性は否定できない，しかし，実験を通して，八エ がトマトの花に飛来する姿もまったく観察されなかったこ とから，実用的な着果促進効果は期待できないと考えられ る. 秋季の ‘シンディースイート’ に拈いて，袋かけ区の 着果率が放任区よりも有意に小さくなった。袋かけ処理に 当たっては，開花前の果房を，ネットの内側が花に触れな いよう被覆した。しかし, 果房の発育に伴い, 花がネット 内側に触れていたことが着果へ何らかの負の影響を及ぼし た可能性がある.

以上のように, メロン，ナス，トマトに拈いてはヒロズ キンバエによる明確な受粉効果は認められなかったことか ら，ミッバチに代わる花粉媒介者としての利用の実用性は 小さいと考えられた.

イチゴに拈いては, 品種により若干の違いがあるものの, 西本ら（2012，2014）も述べていると打り，ヒロズキンバ エの放飼によって正常果率が向上し，花粉媒介者として十 分な実用性を期待できることが明らかになった。，八エは羽 化開始直後から盛んにイチゴの花に飛来し，3 週間程度で 効果の低下が認められたが，低温期には 2 週間以上にわ たってミッバチと同等の受粉効果が維持された (第 2 図). 継続的に利用する場合は，2 週間ごとに搬入することで安 定した効果が得られると考えられる。 また，搬入から羽化 
までに数日かかる場合があることを考慮すると, 最初の搬 入は開花開始の数日前に行らのが望ましいといえる.

搬入するサナギの数に関しては, 面積 $90 \mathrm{~m}^{2}$ のハウスを 用いた場合，“さが臣の’では400 頭でも十分な効果が あった（第 3 図）。一方で，“さちのか’ と ‘福岡 S6 号” は“さが核のか’ と比較して正常果率が劣った. 2012 年 には 1000 頭，2014 年には 400 頭を 2 回連続（4 月 3 日, 7 日）で搬入した場合には“さが核のか’と同時に開花した 花はほとんどが正常果となったことから，これらの品種に おいては 400 頭では安定した受粉効果を得るには不十分で あったと考えられる.

11 月 8 日のペルメトリン散布直後に搬入したハエ (11/9400）は羽化が遅れ，その後の正常果率も比較的低く推移 した，正確な羽化率の調査は行っていないが，羽化した八 エの個体数不足以外に，ペルメトリンによる忌避効果が八 エの訪花を抑制した可能性についても考慮する必要がある だろら。ただし，1週間後に搬入した八エ（11/16-400）は 搬入 2 日後に羽化が始まり，羽化開始後は正常果率が高く 推移した。. ミッバチには長期間悪影響が残るとラベルに明 記されているペルメトリンであっても， 1 週間余りで八エ に対する悪影響は皃ぼ消失したと推察された。

2014 年 4 月 15 日に散布したスピノサドは, 散布 2 日後 にはミッバチを導入可能とされている（ダウ・アグロサイ エンス日本, 2015). このスピノサドの散布によって, そ れ以前に搬入していた八エの受粉効果は急激に低下した (第 4 図). 農薬に対する八エの反応については，今後検討 を重ねる必要があるだろら。

イチゴハウス内に拈いて，八エを放飼した場合，受精不 良果発生率が品種によって異なり, 八エの受粉効果には明 らかな品種間差があることが報告されている（西本ら， 2014)。本実験に拈いて, “福岡 S6 号’は2012 年, 2013 年いずれに拈いても他品種に比べ正常果率が低かった。 し かし，実験を通して比較的正常果率の高かった“さが核の か’より ‘福岡 S6 号” の汪らが花粉稔性は高かった（第 1 表).八エやミッバチは砂糖のみよりも, アミノ酸を含 む糖の混合物を好む傾向があり，これらの昆虫は花蜜中の アミノ酸を識別できる可能性がある（Gardener・Gillman, 2002)。また, サトイモ科 (Araceae) やラン科 (Orchidaceae) の一部の種は, 腐肉や粪を好む八工を引き寄せるために悪 臭を放つこと（ハーレー，2011），Usia bicolor Macquart や ヒツジキンバエ (Lucilia cuprina L.) の訪花行動は, 花弁 の色（Fukushi, 1989） や形（Johnson・Dafni, 1998）に影響 されることが知られている. 八エの訪花頻度の品種間の違 いについては十分な調査ができていないが，八エの味覚や 臭覚, 視覚にかかわる情報は八エの訪花活動に大きく影響 すると考えられ，人間には知覚できない香気成分や，花蜜 の組成に対するハエの嗜好性が，品種間の受粉効果の違い に影響している可能性が考えられる.

八エの搬入を繰り返すうちに，八ウス内でのクモ類の増
加が確認された. クモ類としては徘徊性のコモリグモ科が 最も多く，しばしば八エの死骸を運ぶ姿が観察され，エサ として利用していたと推察された。 クモ類は捕食対象に消 化液を注入し，液体にして飲み込む性質がある（オトゥ一 ル，1987）。羽化しなかったサナギの一部を実体顕微鏡で 観察したところ，食害痕とみられる穴の存在が確認され， サナギを入れたプラスチックケースを天井から吊り下げる ことで, 羽化率が高くなったことから，2014年 2 〜 月 に羽化率が低下した原因は，クモ類による食害と考えられ た. 一方，クモ類が大量に発生している間，アブラムシ類

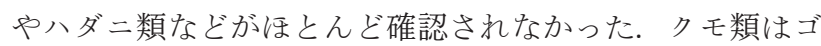
キブリやダニを捕食する益虫としての働きを持つ（国見， 1994）ことが知られている. 水田や一部の露地野菜につい ては天敵としてのクモ類を調査した事例（小林・柴田, 1973）があるが，施設栽培で天敵として評価した研究例は ない.八エの搬入は八ウス内でのクモ類の増殖を促し，間 接的に減農薬につながる可能性があり，八ウス内の生物相 の変化についても今後検討する価值があると考光られる.

本実験に拈ける八エの行動に注目すると, ナス, トマト では八エの訪花は観察されず, メロンでは羽化後数日経つ と，花に飛来する姿が散見されたものの，柱頭付近を盛ん に動き回ることはなかった.これらの果菜類とは対照的に, イチゴに扮いては，八エは羽化直後から盛んに訪花し，多 い時には同時に 5 頭以上のハエが 1 つの花の上を動き回る 姿が観察された。 八エの花に対するこのよらな反応の違い の要因の一つに，花蜜の有無が挙げられる，イチゴは花蜜 を有するが，ナス报よ゙トマトの花は比較的花蜜に乏しい （みつばち協議会，2011）ことから，八工は花蜜の有無を 識別し，花蜜を求めてイチゴの花に飛来していると推察さ れる.メロンの花は，イチゴと同様に花蜜を有する（みつ ぼち協議会，2011）が，八エの訪花がイチゴほど盛んでな かったのは，上述した花蜜の組成や分泌量の違いなどが影 響しているのかもしれない，以上のように，八エを花粉媒 介者として利用するためには，対象植物の花が豊富な花蜜 を有することが必要である可能性が高い.イチゴ以外の果 菜では，この条件を満たす作物は見当たらないが，施設栽 培の果樹では，マンゴー以外にもヒロズキンバエを花粉媒 介者として利用できる可能性があり，今後検討する必要が あると考えられる。

\section{摘 要}

近年，受粉用ミッバチがしばしば不足し，果実を中心に 園芸作物の生産コスト増大や品質低下を引き起こしてい る。 その解決策の一つとして，医療用の無菌ウジ増殖技術 を応用して生産したヒロズキンバエについて，施設栽培作 物の花粉媒介昆虫としての実用化の可能性を検討した．イ チゴ，トマト，ナス拈よびメロンを対象として，開花期に ヒロズキンバェを八ウス内に放飼し，着果率や果実形態の 比較によって, 各作物への受粉効果を調查した。 トマト, 
ナスおよびメロンに括いては, 明確な着果促進効果は得ら れなかった。一方，イチゴでは，八エは羽化直後から盛ん に花に飛来する姿が観察され，八工搬入前と比較して受精 不良果発生率は大きく低下した。 ただし， $90 \mathrm{~m}^{2}$ 当たり 400 頭の搬入では品種によって効果が不十分であった。 し かし，1000 頭搬入した場合は，ミッバチと同等の効果が 得られたことから，ヒロズキンバエはミッバチの代替ポリ ネーターとして十分利用可能であると考えられた.

\section{引用文献}

ダウ・アグロサイエンス 日本．2015．農業・芝・緑地用 製品. スピノエース顆粒水和剤. 〈http://www.dowagro. com/jp/ryosho/prod/spinoacedf.htm $\rangle$.

福田通男. 1960. 農村の各種発生源附近で採集した八工蛹 の季節的消長. 長崎大学風土病紀要. 2: 281-286.

Fukushi, T. 1989. Learning and discrimination of coloured papers in the walking blowfly, Lucilia cuprina. J. Comp. Physiol. A. 166: 57-64.

Gardener, M. C. and M. P. Gillman, 2002. The taste of nectar-a neglected area of pollination ecology. OIKOS. 98: 552-557. DOI: 10.1034/j.1600-0706.2002.980322.x. 〈http://onlinelibrary. wiley.com/doi/10.1034/j.1600-0706.2002.980322.x/full〉.

Garibaldi, L. A., I. Steffan-Dewenter, R. Winfree, M. A. Aizen, R. Bommarco, S. A. Cunningham, C. Kremen, L. G. Carvalheiro, L. D. Harder, O. Afik, I. Bartomeus, F. Benjamin, V Boreux, D. Cariveau, N. P. Chacoff, J. H. Dudenhöffer, B. M. Freitas, J. Ghazoul, S. Greenleaf, J. Hipólito, A. Holzschuh, B. Howlett, R. Isaacs, S. K. Javorek, C. M. Kennedy, K. M. Krewenka, S. Krishnan, Y. Mandelik, M. M. Mayfield, I. Motzke, T. Munyuli, B. A. Nault, M. Otieno, J. Petersen, G. Pisanty, S. G. Potts, R. Rader, T. H. Ricketts, M. Rundlöf, C. L. Seymour, C. Schüepp, H. Szentgyörgyi, H. Taki, T. Tscharntke, C. H. Vergara, B. F. Viana, T. C. Wanger, C. Westphal, N. Williams and A. M. Klein. 2013. Wild pollinators enhance fruit set of crops regardless of honey bee abundance. Science 339: 1608-1611.

Goulson, D. 2010. Impacts of non-native bumblebees in Western Europe and North America. Appl. Entomol. Zool. 45: 7-12. ハーレー マデリン, 2011. 世界で一番美しい花粉図鑑. p. 109. 武井摩利 訳. 創元社. 大阪.

ジャパンマゴットカンパニー． 2015. 安全で清潔な受粉が できるビー・フライ。〈http://www.japan-maggot.com/〉.

JATAFF（公益社団法人農林水産・食品産業技術振興協会）. 2015. 釣り飭の商虫列伝. 商虫列伝（2）養殖もの. $\langle$ https://www.jataff.jp/konchu/bait/10.html〉.

Johnson, S. D. and A. Dafni. 1998. Response of bee-flies to the shape and pattern of model flowers: implications for floral evolution in a Mediterranean herb. Functional Ecology. 12:
289-297.

小林森巳. 1972. 訪花昆虫増殖利用保護に関する研究. シ マハナアブ (Eristalis cerealis Fabricius) の人工増殖. 岩手園試報. 2: 1-27.

小林四朗・柴田広秋. 1973. 水田とその周辺に拈けるクモ 類の個体群変動，害虫の生態的防除々関連して。応動 昆. 4: 193-202.

国見裕久. 1994. 害虫の天敵としてのクモ。 p. 309 . 動物 たちの地球. 3. 昆虫. 朝日新聞社. 東京.

みつばち協議会編. 2011. みつばちにらまく動いてもらら ために. p. 1-15. みつばち協議会（社団法人日本養蜂 はちみつ協会内). 東京.

光畑雅宏. 2014. マルハナバチの利用. p. 459-462. 農業 技術体系野菜編. 2. トマト. 農文協. 東京.

三井秀也・川畑拓也・黒子洋介・鵜垣伸也・大澤 晋 藤井泰宏・石野幸三・河田政明・佐野俊二. 2005 . Diabetic foot に対するウジムシ治療. J. Japan Coll. Angiol. 45: 443-450.

宮本雅章. 2012. 八チの活用方法. p. 139-141. 農業技術 体系野菜編. 3. イチゴ. 農文協. 東京.

水野宗衛・吉田忠晴・清川一真・佐々木正己. 2010. マン ゴー ‘アーウィン’ に拈ける 3 種ハナバチの訪花特性 扣よび受粉効果. ミッバチ科学. 27: 123-132.

西本登志・皆巳大輔・東 君枝 - 安川人央 - 矢奥泰章. 2014 . 花粉媒介昆虫の違いがイチゴの収穫量と奇形果率に及 ぼす影響，並びに開花までの花蕾への覆いが‘熊研い 548’の果実の形状に及ぼす影響. 園学研. 13(別 2): 446. 西本登志・皆巳大輔・安川人央・吉田裕一. 2012. 七イヨウ ミッバチの訪花がイチゴ'アスカルビー’と ‘古都華’ の果実の形状に及ぼす影響. 園学研. 11 (別 2): 433. オトゥール クリストファー. 1987. 動物大百科. p. 153. 小野展嗣 訳. 矢島 稔 編. 平凡社. 東京.

末永 斂. 1959. 八工類の生態的研究. 2. ゴミ箱から発生 するハ工類について. 1:77-84. 長崎大学風土病紀要.

田中 肇. 1994. 花粉学辞典. p. 216-217. 日本花粉学会 編. 朝倉書店. 東京.

van der Sluijs, J. P., N. Simon-Delso, D. Goulson, L. Maxim, J. M. Bonmatin and L. P. Belzunces. 2013. Neonicotinoids, bee disorders and the sustainability of pollinator services. Curr. Opin. Environ. Sustain. 5: 1-13.

Yan, P. 2009. Effect of feeds in developing the hypopharyngeal gland of nosema-free nurse bees for escorting queen honey bees (Apis mellifera) during export. Ph. D. Thesis. BSc Murdoch Univ. Murdoch.

米田昌浩・土田浩治・五箇公一．2008．商品マルハナバチ の生態リスクと特定外来生物. 応動昆. 52: 47-62.

吉田裕一・松野大樹・後藤丹十郎・高田圭太. 2010. 根域 制限栽培に打忷るトマトの生育・収量と果実品質. 岡 山大農センター報告. 32: 9-14. 